\title{
ПРОТИАНЕМІЧНА ДІЯ ПРЕПАРАТІВ ФЕРУМУ У ПОРОСЯТ
}

\author{
Духницький Володимир Богданович \\ доктор ветеринарних наук, просресор \\ Національний університет біоресурсів і природокористування України
} ORCID: 0000-0002-9670-1244

Деркач Ірина Михайлівна

кандидат ветеринарних наук, доцент Національний університет біоресурсів і природокористування України ORCID: 0000-0002-0149-7923 Irina1215@ukr.net

Деркач Сергій Стеанович

кандидат ветеринарних наук, доцент, Національний університет біоресурсів і природокористування України ORCID: 0000-0002-6174-1377

Фрицький Ігор Олегович, доктор хімічних наук, просресор, Київський національний університет імені Тараса Шевченка ORCID: 0000-0002-1092-8035

Плутенко Максим Олександрович кандидат хімічних наук, науковий співробітник Київський національний університет імені Тараса Шевченка ORCID: 0000-0002-9369-0711

У статті наведені результати досліджень протианемічної дії в організмі поросят Феруму у формі клатрохелату та у рідкісній нетрадиційній валентності IV. Дослідження проведено на поросятах-аналогах, яких розподілили у дві групи - контрольну та дослідну. Поросята дослідної групи були відібрані від свиноматок, яким у період вагітності двічі внутрішньом'язово вводили по 10 мл 10 \% розчину клатрохелату Феруму(IV). Матеріалом для досліджень були маса тіла та сироватка крові поросят. Дослід тривав 60 діб.

Результати досліджень засвідчили відсутність загибелі та анемії серед поросят дослідної групи, високу інтенсивність їх росту, що вказує на профрілактичний ефект клатрохелату Феруму(IV), застосованого поросним свиноматкам. Встановлено, що маса тіла поросят дослідної групи не відрізнялась від маси тіла поросят контрольної групи; була меншою на 5 добу їх життя та перевищувала в усі послідуючі періоди вирощування, аж до відлучення. Нижчий вміст Феруму у сироватці крові поросят дослідної групи, ніж у контролі до 12 добового віку пояснюється особливостями його фармакокінетики - впливом плацентарного бар'єру.

Ключові слова: анемія, ферум, гексагідразидний клатрохелат, поросята, свиноматки.

DOI: https://doi.org/10.32845/bsnau.vet.2020.4.7

Вступ. Анемія є однією з найбільш поширених незаразних хвороб новонароджених ссавців. В сучасних умовах ведення свинарства важливим завданням, яке не втрачає актуальності, $€$ забезпечення потреби новонароджених поросят у Ферумі (Evans \& Abraham, 1973; Walter et al., 1997; Killip \& Bennett, 2008; Ganz, 2013; Kim et al., 2018). Проте, слід зазначити, що безпечний діапазон вмісту Феруму в організмі достатньо вузький і повинен суворо контролюватися, щоб уникнути як дефіциту Феруму, так і його надлишку.

Загальновідомо, що Ферум є необхідним елементом для забезпечення життєдіяльності усіх живих організмів. Він входить до складу функціональних груп білків, що транспортують Оксиген, та ензимів, що каталізують реакції утворення енергії та контролюють перебіг метаболічних процесів.

Основна кількість Феруму, необхідного живому організму, надходить з макрофагів за його рециркуляції із старіючих еритроцитів. Цей процес здійснюється за допомогою фреропортину, гемової оксидази, дуоденального транс-

портера двохвалентних металів (DMT11), а регулюється декількома протеїнами, до числа яких належать білок спадкового гемохроматозу (HFE), фрерумзв'язувальні елементи (IRE) та ферумзв'язувальний протеїн (IRP) (Roy \& Enns, 2000).

Ступінь розвитку біологічних і медичних наук наразі дозволяє стверджувати, що гепсидин $є$ основним регуляторним пептидом, що забезпечує гомеостаз Феруму в організмі. Наукові пошуки тривають, і очікується, що будуть встановлені нові субстанції, ключові знання особливостей обміну яких дозволить здійснювати профрілактику порушень обміну Феруму у клінічній практиці (Ganz \& Nemeth, 2006; Camaschella, 2013: Видиборець \& Андріяка, 2017).

В організмі поросят у перші тижні життя внаслідок «фрізіологічної» недостатності даного мікроелементу швидко розвивається ферумдефіцитна анемія. Відомо, що з молозивом матері порося отримує близько 1 мг Феруму за добу, а добова потреба в ньому становить 7-10 мг (Карпуть \& 
Николадзе, 2001, 2003; Devillers et al., 2004; Svoboda \& Drabek, 2005; Leyshon et al., 2016). Поросята віком 3 тижні потребують вже 114-200 мг Феруму, в той час як з молоком вони одержують лише 23-24 мг (Карелін, 1983).

Крім того, встановлено, що поросята, порівняно 3 тваринами інших видів, інтенсивно збільшують масу тіла майже вдвічі щотижня, що значно випереджає формування кровотворних органів та досконалість їх функціональної діяльності (Framstand \& Sjaastad, 1991; Zimmermann, 1995; Kegley et al., 2002; Левченко та ін., 2012).

Гіпопластична анемія (anaemia hypoplastica) - хвороба, що характеризується зменшенням кількості еритроцитів та вмісту гемоглобіну або одного з цих показників в одиниці об'єму крові внаслідок порушення кровотворення і кісткового гемоцитопоезу, змінами обміну речовин та затримкою росту. У поросят захворювання починає розвиватися 3 5-7-добового віку і максимального розвитку досягає через три тижні після народження. Таким чином, дефіцит Феруму $є$ поширеною патологією, а основою її профрілактики $€$ застосування відповідних препаратів (Батраков та ін., 2005).

Сучасна профілактика ферумдефіцитної анемії та фармакотерапія за цієї патології основані, перш за все, на внутрішньом'язовому введенні поросятам ферумдекстранових засобів: фероглюкін, фреродекс, ферро-100, ферровет$7,5 \%$, декстрофер-100, урзоферан 100, броваферан-100 тощо Ці препарати застосовують на 2-5 добу після народження, а потім через 7-10 діб з розрахунку 100-150 мг Феруму на ін'єкцію (Данчук, 2002; Веред, 2003; Деркач, 2017; Левченко та ін., 2012).

Застосування препаратів Феруму свиноматкам для профілактики ферумдефіцитної анемії народжених від них поросят $€$ дискусійним питанням. Описано різні схеми профрілактики цієї патології, коли, наприклад, змащують вим'я свиноматок розчином Феруму сульфату у період годування поросят або застосовують ферумумісні препарати поросним свиноматкам. Проте інші вчені спростовують ефективність таких схем.

Мета роботи - порівняти ефективність застосування клатрохелату Феруму(IV) поросним свиноматкам та ферумдекстранового препарату новонародженим поросятам на основі аналізу маси тіла поросят, умісту Феруму та Купруму у їх сироватках крові.

\section{Матеріал та методи дослідження}

Для виконання поставленої мети було сформовано 2 групи новонароджених поросят-аналогів (гібриди порід ландрас та велика біла) у період їх утримання зі свиноматками на підсосі - контрольна та дослідна, по 15 тварин у кожній.

Поросята дослідної групи були відібрані від 5-ти свиноматок (по 3 від кожної), яким в період вагітності двічі (за 14 та 7 діб до очікуваного опоросу) внутрішньом'язово вводили по 10 мл 10 \% розчин клатрохелату Феруму(IV). Поросятам контрольної групи за традиційною схемою профрілактики ферумдесріцитної анемії на другу добу життя вводили ферумдекстрановий препарат у дозі 2 мл для тварини.
Діючою речовиною препарату, що застосовували свиноматкам, $є$ Ферум у рідкісній валентності IV та у формі клатрохелату - це макробіциклічний комплекс, у якому іон металу «упакований» у нанокапсулу, яка перешкоджає взаємодії 3 переважною більшістю реагентів, зокрема, біолігандами, а також екранує метал від інших факторів навколишнього середовища. Вперше про синтез унікальних клатрохелатних сполук Феруму(IV) було повідомлено Tomyn et al. (2017). Ми провели ряд доклінічних досліджень їх гострої та хронічної токсичності, кумулятивних властивостей та клінічних досліджень (Духницький із співавт., 2018, 2019, 2020).

Використаний нами розчинник реополіглюкін $є$ плазмозамінним колоїдним розчином декстрану (полімеру глюкози).

Протягом 2 місяців за поросятами вели спостереження, зважували на 1, 5, 9, 12, 30 та 60 доби після народження та визначали динаміку змін маси тіла поросят контрольної та дослідної груп; для досліджень умісту Феруму та Купруму в сироватці крові поросят відбирали зразки крові на $1,5,9,12,30$ та 60 доби життя.

Результати досліджень. Упродовж наукововиробничого досліду, який тривав 2 місяці, особливу увагу було зосереджено на змінах в організмі поросят дослідної групи, у ймовірний період прояву ферумдефіцитної анемії, оскільки акцентувалося на вивченні нової схеми профрілактики даної патології, впливу клатрохелату Феруму(IV), введеного у період вагітності поросним свиноматкам, на подальший розвиток молодняка свиней.

У результаті проведених досліджень не було відмічено народження мертвих поросят та не спостерігали будь-яких клінічних ознак анемії. Нами не відмічалася блідість слизових оболонок (з жовтуватим відтінком), скуйовдженість щетини, сухість чи зморщення шкіри поросят, прискорений пульс та пришвидшений ритм дихання у них, що характерно для прояву анемії. У всіх поросят за період досліду не виявляли відставання у рості, розладів травлення, малорухливості.

Поросята активно ссали свиноматок, природньо займали соски з більшим рівнем лактації молочних пакетів, що відповідно впливало на збільшення їх маси тіла. Слід відзначити, що поросята дослідної групи були більш активними, ніж поросята контрольної групи, що підтверджує дані Приступи Т.І. із спіавт. (2013), які доводять, що дефіцит Феруму в організмі поросят-сисунів призводить до зниження рухливості та тривалості ссання молока свиноматки.

Зміни маси тіла дослідних тварин, порівняно з контролем, $€$ дуже вагомим показником, порушення якого свідчить про ступінь неблагополуччя в організмі. Зміни маси тіла особливо важливі для молодих підростаючих тварин; зі збільшенням віку приріст маси відбуваєтся значно повільніше (Коцюмбас Я.І., 2007).

На першу добу життя різниці у масі тіла поросят контрольної та дослідної груп не було (табл. 1). 
Таблиця 1.

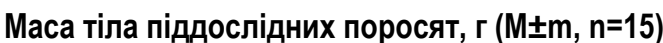

\begin{tabular}{|l|c|c|}
\hline \multirow{2}{*}{ Вік поросят, діб } & \multicolumn{2}{|c|}{ Група поросят } \\
\cline { 2 - 3 } & І контрольна & II дослідна \\
\hline 1 & $1781,0 \pm 26,79$ & $1706,9 \pm 31,09$ \\
\hline 5 & $2858,0 \pm 62,63$ & $2191,8 \pm 82,12^{\star * *}$ \\
\hline 9 & $3145,9 \pm 87,22$ & $3263,3 \pm 141,35^{*}$ \\
\hline 12 & $3603,8 \pm 61,41$ & $4110,8 \pm 175,77^{*}$ \\
\hline 30 & $7583,3 \pm 84,63$ & $10262,2 \pm 333,76^{* * *}$ \\
\hline 60 & $20266,7 \pm 270,75$ & $25574,4 \pm 957,20^{* * *}$ \\
\hline
\end{tabular}

Маса тіла поросят віком 5 діб дослідної групи була в 1,3 раза вірогідно меншою, ніж маса тіла поросят контрольної групи. Слід зауважити, що на другу добу життя поросятам контрольної групи було введено традиційний ферумдекстрановий препарат, що забезпечував вплив на обмін речовин та загальний стан організму тварин.

На 9, 12, 30 та 60 доби життя маса поросят дослідної групи зростала інтенсивніше, ніж маса тіла поросят контрольної групи і була більшою в $1,03,1,14,1,35$ та 1,26 раза відповідно, порівняно з контролем.

Відомо, що дослідження вмісту Феруму в сироватці крові важливе для скринінгу, діагностики ферумдефіцитних анемій, а також для оцінки ефективності лікування хворих на ферумдефіцитну анемію. Тому одним із завдань нашого дослідження було визначення умісту Феруму у сироватці крові поросят за впливу різних ферумвмісних препаратів (табл. 2).

Уміст Феруму у сироватці крові поросят

Таблиця 2.

за впливу різних ферумумісних препаратів, ммоль/л (M士m, n=15)

\begin{tabular}{|l|c|c|}
\hline \multirow{2}{*}{ Вік поросят, діб } & \multicolumn{2}{|c|}{ Група поросят } \\
\cline { 2 - 3 } & І контрольна & ІІ дослідна \\
\hline 1 доба & $3,2 \pm 0,43$ & $3,8 \pm 0,76$ \\
\hline 5 доба & $8,5 \pm 0,14$ & $4,2 \pm 0,46^{* * *}$ \\
\hline 12 доба & $22,6 \pm 0,44$ & $6,8 \pm 0,52^{\star * *}$ \\
\hline 30 доба & $14,7 \pm 0,29$ & $14,5 \pm 1,17$ \\
\hline
\end{tabular}

Примітка: ступінь вірогідності - ** - p<0,01, ${ }^{* * \star}-p<0,001$; порівняно з показником у поросят контрольної групи .

У сироватці крові новонароджених (на 1 добу) поросят дослідної групи вміст Феруму був незначно вищим, оскільки всі вони були народжені від свиноматок, яким двохразово вводили препарат Феруму(IV) у період вагітності. На 5 добу життя даний показник був удвічі вищим у поросят контрольної групи порівняно з таким у сироватці крові поросят дослідної групи, що можна пояснити тим, що згідно традиційної схеми профрілактики ферумдесфіцитної анемії, поросятам контрольної групи на 2 добу життя вводили ферумдекстрановий препарат. Слід зазначити, що жодних клінічних ознак анемії у поросят дослідної групи не спостерігалося. Такою ж була тенденція і на 12 добу життя поросят, проте на 30 добу, коли вже минув критичний період розвитку ферумдефіцитної анемії, уміст Феруму у сироватці крові поросят контрольної та дослідної груп не відрізнявся.
Важливе значення для організму тварин має вміст Купруму, оскільки цьому мікроелементу належить важлива біологічна роль у гемоцитопоезі: Купрум прискорює окиснювально-відновні реакції у клітинах, сприяє утворенню гемоглобіну, накопиченню Феруму «про запас». За нестачі Купруму у тварин розвивається анемія, у поросят, крім того, уражається центральна нервова система, розм'якшуються і демієлінізуються рухливі нервові волокна спинного мозку, що призводить до порушення координації руху, виникнення паралічу. Існує твердження, що за десріциту Феруму в організмі збільшується уміст Купруму (Полковенко О.В., 2010).

Нами досліджено вплив Феруму у складі різних ферумвмісних препаратів на вміст Купруму у сироватці крові поросят (табл. 3).

Уміст Купруму у сироватці крові поросят

Таблиця 3. за впливу різних ферумвмісних препаратів, ммоль/л (M士m, n=15)

\begin{tabular}{|l|c|c|}
\hline \multirow{2}{*}{ Вік поросят, діб } & \multicolumn{2}{|c|}{ Група поросят } \\
\cline { 2 - 3 } & І контрольна & |І дослідна \\
\hline 1 & $16,0 \pm 0,17$ & $16,5 \pm 0,16$ \\
\hline 12 & $18,0 \pm 0,26$ & $17,1 \pm 0,24^{\star *}$ \\
\hline 30 & $20,8 \pm 0,41$ & $21,3 \pm 0,57$ \\
\hline
\end{tabular}

Примітка: ступінь вірогідності - ** - $p<0,01,{ }^{* * *}-p<0,001$; порівняно з показником у поросят контрольної групи.

Уміст Купруму у сироватці крові поросят дослідної (застосовували їх матерям клатрохелат Феруму(IV)) та контрольної (застосовували новонародженим поросятам традиційний ферумдекстрановий препарат) груп був майже однаковим упродовж періоду досліду та знаходився у межах фізіологічних коливань.

\section{Висновки}

Метою науково-виробничого досліду, який тривав 2 місяці, було вивчення нової схеми профілактики ферумдефіцитної анемії поросят, а саме впливу клатрохелату Феруму (IV), введеного поросним свиноматкам у період вагітності, на зміни в організмі народжених від них поросят у 
ймовірний період прояву даної патології та на подальший розвиток молодняка свиней.

Відсутність загибелі, ознак анемії чи іншої патології серед поросят дослідної групи вказувала на профілактичний ефект клатрохелату Феруму (IV), застосованого поросним свиноматкам. Поросята активно ссали свиноматок, природньо займали соски з більшим рівнем лактації молочних пакетів, що відповідно впливало на збільшення їх маси тіла. Маса тіла поросят, народжених від свиноматок, яким у період вагітності застосовували клатрохелату Феруму (IV), не відрізнялась від маси тіла поросят контрольної групи; була меншою на 5 добу їх життя, та перевищувала в усі послідуючі періоди вирощування, аж до відлучення.

Нижчий вміст Феруму у сироватці крові поросят дослідної групи, ніж у контролі до 12 добового віку, пояснюється особливостями його фармакокінетики - впливом плацентарного бар'єру.

\section{References}

1. Batrakov, A., Travkin, O., \& Jakovleva, E. (2005). Profilaktika alimentarnoj anemii u porosjat [Prevention of malignant anemia of piglets]. Veterinarija [Veterinary medicine], 12, 44-45 [in Russian].

2. Camaschella C. (2013). Iron and hepcidin: a story of recycling and balance. Hematology. American Society of Hematology. Education Program, 2013, 1-8. https://doi.org/10.1182/asheducation-2013.1.1

3. Ganz, T., \& Nemeth, E. (2006). Iron imports. IV. Hepcidin and regulation of body iron metabolism. American journal of physiology. Gastrointestinal and liver physiology, 290(2), 199-203. https://doi.org/10.1152/ajpgi.00412.2005

4. Danchuk, V. (2002). Profilaktyka anemii u novonarodzhenykh porosiat [Prevention of anemia in newborn piglets]. Tvarynnytstvo Ukrainy [Livestock of Ukraine], 2. 23-25.

5. Derkach, I. (2017). Suchasni tendencii' na vitchyznjanomu rynku ferumvmisnyh preparativ dlja tvaryn [Modern trends of the Ukrainian market of ironcontaining products for animals]. Naukovyj visnyk Lvivskogo nacionalnogo universytetu veterynarnoi medycyny ta biotehnologij imeni S. Z. Gzhyckogo [Scientific Messenger of LNU of Veterinary Medicine and Biotechnologies. Series: Veterinary Sciences], 19(78), 23-25. doi.org/10.15421/nvlvet7805 [in Ukrainian].

6. Devillers N., Milgen van J., Prunier A. \& Le J. Dividich (2004) Estimation of colostrum intake in the neonatal pig Animal Science, 78, 305-313.

7. Dukhnitsky, V. B., Derkach, I. M., Plutenko, M. O., Fritsky, I. O., \& Derkach, S. S. (2018). Vyznachennja parametriv gostroi toksychnosti ferumu (IV) na bilyh myshah [Determination of the accumulative toxicity parameters of iron (IV) on white mice]. Ukrainian Journal of Ecology, 8 (2), 308-312. doi.org/10.15421/2018_343 [in Ukrainian].

8. Dukhnitsky, V., Derkach, I., Derkach, S., Fritsky, I., \& Plutenko, M. (2019). Khronichna toksychnist klatrokhelatu Ferumu (IV) dlia bilykh shchuriv [Chronic toxicity of the Iron (IV) clathrochelate complexes for white rats]. Naukovyj visnyk Lvivskogo nacionalnogo universytetu veterynarnoi medycyny ta biotehnologij imeni S. Z. Gzhyckogo [Scientific Messenger of LNU of Veterinary Medicine and Biotechnologies. Series: Veterinary Sciences], 21(95), 15-21. https://doi.org/10.32718/nvlvet9503 [in Ukrainian].

9. Dukhnitsky, V. B., Derkach, I. M., Plutenko, M. O., Fritsky, I. O., \& Derkach, S. S. (2019). Cumulative properties of Iron(IV) clathrochelate in rats [Kumuliatyvni vlastvosti klatrokhelatu Ferumu (IV) dlia bilykh shchuriv]. Visnyk PDAA [Messenger PDAA], 2, 238-246. doi: 10.31210/visnyk2019.02.32 [in Ukrainian].

10. Dukhnitsky, V., Derkach, I., Plutenko, M., Fritsky, I., \& Derkach, S. (2019). Acute toxicity of the iron clathrochelate complexes. Regulatory Mechanisms in Biosystems, 10(3), 276-279. https://doi.org/10.15421/021942

11. Dukhnitsky, V. B., Derkach, I. M., Derkach, S. S., Plutenko, M. O. \& Fritsky, I. O. (2019). Influence of iron (IV) clathrochelate complex on quail blood parameters and weight characteristics. Ukrainian Journal of Ecology, 9 (3), 126-131. DOI: 10.15421/2019_719

12. Dukhnitsky, V., Derkach, I., Derkach, S., Fritsky, I., \& Plutenko, M. (2020). Doslidzhennia podrazniuvalnoi dii ta alerhennykh vlastyvostei klatrokhelatu Ferumu(IV) [Investigations of the irritant effect and allergenic properties of Fermat's clatrochelate (IV)]. Naukovyj visnyk Lvivskogo nacionalnogo universytetu veterynarnoi medycyny ta biotehnologij imeni S. Z. Gzhyckogo [Scientific Messenger of LNU of Veterinary Medicine and Biotechnologies. Series: Veterinary Sciences], 22(97), 130-135. doi: 10.32718/nvlvet9721 [in Ukrainian].

13. Dukhnitsky, V., Derkach, I., Derkach, S., Fritsky, I., \& Plutenko, M. (2020). Doslidzhennia protyanemichnoi dii klatrokhelatu Ferumu(IV) na porosiatakh [Study of the antianemic effect of iron (IV) clatrochelate on piglets]. Naukovyj visnyk Lvivskogo nacionalnogo universytetu veterynarnoi medycyny ta biotehnologij imeni S. Z. Gzhyckogo [Scientific Messenger of LNU of Veterinary Medicine and Biotechnologies. Series: Veterinary Sciences], 22(99), 107-115. doi: 10.32718/nvlvet9917 [in Ukrainian].

14. Dukhnitsky, V. B., Kalachniuk L.H., Derkach, I. M., Derkach, S. S., Plutenko, M. O. \& Fritsky, I. O. (2020). Iron(IV) hexahydrazide clathrochelate complexes: the chronic toxicity study Ukrainian Journal of Ecology, 9 (3), 18-23. DOI: 10.15421/2020_3

15. Derkach, I. (2017). Suchasni tendencii na vitchyznjanomu rynku ferumvmisnyh preparativ dlja tvaryn [Modern trends of the Ukrainian market of ferumcontaining products for animals]. Naukovyj visnyk Lvivskogo nacionalnogo universytetu veterynarnoi medycyny ta biotehnologij imeni S. Z. Gzhyckogo [Scientific Messenger of LNU of Veterinary Medicine and Biotechnologies. Series: Veterinary Sciences], 19 (78), 23-25. doi.org/10.15421/nvlvet7805 [in Ukrainian].

16. Evans, J. L., \& Abraham, P. A. (1973). Anemia, Iron Storage and Ceruloplasmin in Copper Nutrition in the Growing Rat. The Journal of Nutrition. 103 (2, 1), 196-201. https://doi.org/10.1093/jn/103.2.196

17. Framstad, T. \& Sjaastad, O. (1991). Iron supplementation in piglets. Norsk Veterinaertidsskrift, , 103, 21-27.

18. Ganz, T. (2013). Systemic iron homeostasis. Physiological Reviews. 93 (4). 1721-1741. doi: 10.1152/physrev.00008

19. Karelyn A.Y. (1983) Anemyia porosiat [Anemia of piglets]. Moskwa. Rosselkhozyzdat [in Russian]. 
20. Karput' I. M., \& Nikoladze M. G. (2001). Diagnostika i profilaktika alimentarnoj anemii porosjat [Diagnosis and prevention of alimentary anemia of piglets]. Veterinarija [Veterinary medicine], 4, 34-37 [in Russian].

21. Karput' I. M., \& Nikoladze M. G. (2003). Obmen zheleza u zdorovyh i bol'nyh alimentarnoj anemiej porosjat [Iron metabolism in healthy and sick piglets with alimentary anemia]. Bulletin of the Academy of Agrarian Sciences of the Republic of Belarus [Izvestiya Akademii Agrarian Sciences of the Republic of Belarus], 4, 34-37 [in Russian].

22. Kegley E.B., Speers J.W., Flowers W.L., \& Schoenherr W.D. (2002). Iron methionine as a source of iron for the neonatal pig. Nutrition research. 22, 1209-1217.

23. Kim, J.C., Wilcock, P., \& Bedford, M.R. (2018). Iron status of piglets and impact of phytase superdosing on iron physiology: A review. Animal Feed Science and Technology. 235, 8-14.

24. Killip, S., \& Bennett, M. Iron Deficiency Anemia (2008). American Family Physician. 15, 78 (8), 671-678.

25. Kocjumbas I. J. (2006) Doklinichni doslidzhennja veterynarnyh likars'kyh zasobiv [Preclinical studies of veterinary drugs]. L'viv. Triada pljus [in Ukrainian].

26. Leyshon, B. J., Radlowski, E. C., Mudd, A. T., Steelman, A. J., \& Johnson, R. W. (2016). Postnatal Iron Deficiency Alters Brain Development in Piglets. The Journal of nutrition, 146(7), 1420-1427. https://doi.org/10.3945/jn.115.223636

27. Levchenko V. I., Kondrakhin I. P., \& Vlizlo V.V. (2012). Vnutrishni khvoroby tvaryn. Chastyna 1 [Internal diseases of animals. Part 1]. Bila Tserkva.

28. Polkovenko O.V. (2010). Znachennia midi dlia zdorov'ia liudyny [The value of copper for human health]. Kultura bezpeky ekolohii ta zdorovia [Culture of environmental safety and health]. 3, 33-35.

29. Prystupa, T.I., Danchuk, V.V., Danchuk, O.V., \& Kaplunenko V.H. (2013). Rukhova aktyvnist porosiat-sysuniv za vvedennia spoluk ferumu [Motor activity of suckling piglets with the introduction of iron compounds]. Naukovyi visnyk veterynarnoi medytsyny [Scientific Bulletin of Veterinary Medicine], 12(107), 60-63.

30. Roy, C. N., \& Enns, C. A. (2000) Iron homeostasis: new tales from the crypt. Blood, 96(13), 4020-4027.

31. Svoboda, M., \& Drabek, J. (2005). Iron deficiency in suckling piglets: etiology, clinical aspects and diagnosis. Folia Veterinaria., 49, 104-111.

32. Tomyn, S., Shylin, S. I., Bykov, D., Ksenofontov, V., Gumienna-Kontecka, E., Bon, V. \& Fritsky, I.O. (2017) Indefinitely stable iron (IV) cage complexes formed in water by air oxidation. Nature Communications. 8, 1-8.

33. Vered, P. I. (2003). Vyvchennia dii proty anemichnykh preparativ vitchyznianoho vyrobnytstva na orhanizm porosiat [Study of action against anemic drugs of domestic production on the body of piglets]. Zbirnyk materialiv III mizhvuzivskoi naukovopraktychnoi konferentsii aspirantiv "Suchasna ahrarna nauka: napriamy doslidzhen, stan i perspektyvy» [Proceedings of the III Interuniversity Scientific and Practical Conference of Postgraduate Students "Modern Agricultural Science: Areas of Research, Status and Prospects"]. Vinnytsia, 222-223.

34. Vydyborets, S. V. \& Andriiaka, A. O. (2017). Fiziolohichna rol hepsydynu yak tsentralnoho rehuliatora metabolizmu zaliza (Ohliad literatury) [Physiological role of hepcidin as a central regulator of iron metabolism (Literature review)] Semeinaia medytsyna [Family medicine], 1(69), 154-157.

35. Zimmermann, W. (1995). Auswirkungen diverser Anamieprohylaxeformen auf die Blutprameter der Saugferkel. Dtsch. Tierarztl. Wsch., 102, 32-38.

36. Walter, T., Olivares, M., Pizarro, F. \& Muñoz, C. (1997). Iron, Anemia, and Infection. Nutrition Reviews. 55 (4), 111-124. doi: 10.1111/j.1753-4887.1997.tb06462.x

Volodymyr Dukhnitskyi, National University of Life and Environmental Sciences of Ukraine (Kyiv, Ukraine)

Iryna Derkach, National University of Life and Environmental Sciences of Ukraine (Kyiv, Ukraine)

Serhii Derkach, National University of Life and Environmental Sciences of Ukraine (Kyiv, Ukraine)

Igor Fritsky, Taras Shevchenko National University of Kyiv (Kyiv, Ukraine)

Maxym Plutenko, Taras Shevchenko National University of Kyiv (Kyiv, Ukraine)

Antianemic effect of preparations of iron in pigs

Anemia is one of the most common non-communicable diseases of newborn mammals. In modern conditions of pig breeding an important task, which does not lose relevance, is to provide the needs of newborn piglets in Iron. Modern prevention of iron deficiency anemia and pharmacotherapy for this pathology are based primarily on intramuscular administration of iron dextran drugs to piglets.

The article presents the results of studies of antianemic action in the body of piglets Iron in the form of clatrochelate and in rare unconventional valence IV. The study was performed on analogous piglets, which were divided into two groups - control and experimental. Piglets from the experimental group were selected from sows given $10 \mathrm{ml}$ of $10 \%$ Iron(IV) clatrochelate solution twice intramuscularly during pregnancy. Piglets of the control group according to the traditional scheme of prevention of iron deficiency anemia on the second day of life were administered iron dextran drug in a dose of $2 \mathrm{ml}$ for the animal. The material for the research was the body weight and blood serum of piglets. The experiment lasted 60 days.

The results of the studies showed the absence of death and anemia among the piglets of the experimental group, the high intensity of their growth, which indicates the prophylactic effect of Iron(IV) clatrochelate used in pregnant sows. It was found that the body weight of piglets in the experimental group did not differ from the body weight of piglets in the control group; was less than 5 days of their life and exceeded in all subsequent periods of cultivation, up to weaning.

It is known that the study of the content of iron in the serum is important for screening, diagnosis of iron deficiency anemia and to assess the effectiveness of treatment of patients with iron deficiency anemia. Therefore, one of the tasks of our study was to 
determine the content of iron in the serum of piglets under the influence of various iron-containing drugs. The lower content of iron in the serum of piglets of the experimental group than in the control up to 12 days of age, due to the peculiarities of its pharmacokinetics - the effect of the placental barrier.

The content of copper in the serum of piglets of the experimental and control groups was almost the same during the experimental period and was within physiological values.

Key words: anemia, iron, hexahydrazide clatrochelate, piglets, sows.

Дата надходження до редакції: 29.11.2020 р. 